\title{
MODEL JEJARING KAUSALITAS TB ANAK (STUDI KASUS DI KABUPATEN BANYUMAS)
}

\author{
M. Choiroel Anwar ${ }^{1)}$ \\ Jurusan Kesehatan Lingkungan, Politeknik Kesehatan Kemenkes Semarang, \\ Jl. Raya Baturaden KM 12 Purwokerto, Indonesia
}

\begin{abstract}
Abstrak
Faktor yang mempengaruhi kejadian TB anak sangat komplek dan merupakan sesuatu jejaring sebab akibat. Tujuan penelitian adalah mengetahui prevalensi TB anak pada anak yang tinggal serumah dengan penderita BTA positip, mengembangkan model jejaring kausalitas penularan, serta mengetahui hubungan kausal antar faktor risikonya. Jenis penelitian observasional dengan rancangan crossectional. Populasi adalah anak umur kurang 15 tahun yang tinggal serumah dengan penderita TB paru BTA positip. Jumlah sampel 195 anak. Cara mengukur TB anak dengan melakukan tes tuberkulin dan diagnosis kemudian dihitung skornya, sedangkan variabel laten potensi penularan penderita BTA positip, sosial ekonomi, risiko perilaku, kondisi rumah, lingkungan dan kerentanan anak dengan wawancara dan observasi terhadap variabel indikator. Analisis data menggunakan Structural Equation Modelling (SEM). Analisis model pengukuran dengan confirmatory factor analysis(CFA) untuk mengetahui kesesuaian variable indikator dalam menjelaskan variable latennya diketahui bahwa model layak ataupun cocok (Fit). Hasil analisis Structural Model dengan regression weighs untuk melihat hubungan kausal antar variabel laten dapat diketahui dari 12 hipotesis yang diajukan terdapat 9 hipotesis terbukti yakni terdapat hubungan Timbal balik antara kejadian TB paru positip dengan sosial ekonomi, ada pengaruh sosial ekonomi terhadap kondisi perumahan, kondisi lingkungan rumah, perilaku. Ada pengaruh potensi penularan penderita BTA positip, perilaku, kondisi lingkungan, kerentanan anak, sosial ekonomi terhadap kejadian TB anak. Prevalensi TB anak pada keluarga penderita TB BTA positip : 39 \%. Model dinyatakan sesuai (fit) dan terdapat 9 hipotesis terbukti. Implikasi penelitian adalah masalah $\mathrm{Tb}$ anak tidak dapat hanya diselesaikan dengan pengobatan penderita saja tetapi juga perlu diperhatikan semua dimensi jejaring penularan yang telah diteliti pada penelitian ini.
\end{abstract}

Kata kunci : Prevalensi, Jejaring, TB Anak dan SEM

\begin{abstract}
Factors that affecting the incidence of TB to children is very complex and it is a networking infolving multidisiplinary factors and sectors. The purpose of this study is to determine the prevalence of TB in children's who live at home with smear-positive patients later developed a causal model of TB transmission networks proper child (fit) and determine the causal relationship between risk factors. This type of research is observational with cross sectional design. The population is children aged less than 15 years old who live with smear positive pulmonary TB patients. The number of samples were195 children. How to measure TB children with tuberculin test and diagnosis were then calculated the scores, while the latent variable transmission potential of smear positive patients, socioeconomic, behavioral risk, housing conditions, the environment and the vulnerability of children with interviews and observations of the indicator variable. Data analysis using Structural Equation Modeling (SEM). The prevalence $T B$ in children from TB BTA (+) patients' family were $39 \%$. The results of the analysis of the measurement model with confirmatory factor analysis (CFA) to determine the suitability of the indicator variables in explaining the latent variable is known that the model worthy or fit (Fit). The causality between latent variables can be known from 12 proposed of the hypothesis that consist of 9 hypothesis which proved that there is a relationship between the incidence reciprocity pulmonary tuberculosis with positive socio-economic. There is a significant effect of socio-economic to the housing conditions of the respondents, respondents home environment, the behavior of respondents. There is a significant effect of potential infectious smear positive patients, respondent behavior, condition of child home environment, children vulnerably, social economy on the incidence of pulmonary tuberculosis of children. The prevalence child TB positive is $39 \%$. Model were said appropriate (fit) and there are 9 proven hypothesis out of 12 proposed hypothesis. The implication of this research is TB eradication should not only merely focusen on the individual factors of patient but it should cover all dimension of multicaution transmision network found in this research.
\end{abstract}

Keywords : Prevalence, Networking, Child TB, SEM and ANP 


\section{LATAR BELAKANG}

Tuberkulosis paru (TB paru) adalah suatu penyakit yang sudah lama dikenal, tetapi saat ini bangkit kembali menjadi penyakit yang menyebabkan epidemi global (re-emerging disease) di negara maju, sedangkan di Indonesia merupakan penyakit Emerging infectious disease. Sepertiga dari populasi total dunia (sekitar 2 milyar orang) terinfeksi TB dan setiap kasus merupakan faktor risiko penyakit TB karena jika tidak diobati dengan tepat, setiap kasus TB aktif akan menginfeksi 10 hingga 15 orang setiap tahun ${ }^{1}$.

World Health Organization (WHO) dalam Global Report tahun 2012 melaporkan, Indonesia menempati peringkat ke-4 negara insidensi TB tertinggi di dunia dengan jumlah kasus sebanyak 0,37 - 0,54 ${ }^{2}{ }^{4}$. Dari insiden TB secara global dilaporkan sekurang-kurangnya 500.000 penderita adalah anakanak usia $<15$ tahun dan 70.000 anak meninggal setiap tahun akibat TB atau sekitar 200 anak meninggal setiap hari ${ }^{5}$.

Proporsi kasus TB Anak di antara semua kasus TB yang ternotifikasi di Indonesia dalam program TB pada tahun 2010 adalah 9,4\%, kemudian menjadi 8,5\% pada tahun 2011 dan 8,2\% pada tahun 20123. Proporsi TB anak di Kabupaten Banyumas bersumber laporan program TB paru adalah $20 \%$ dari seluruh kasus TB lebih tinggi dari angka nasional dengan proporsi anak usia Balita : $11.74 \%$ dan usia $5-14$ Th : $7.79 \%$, sedangkan proporsi menurut jenis kelamin terdiri dari laki-laki $54 \%$ dan perempuan 46 $\%^{6}$.

Tuberkulosis anak merupakan masalah kesehatan penting di negara-negara berkembang karena jumlah anak usia kurang dari 15 tahun adalah 40-50\% dari jumlah seluruh populasi ${ }^{6-8}$. Angka kesakitan tuberkulosis anak merupakan parameter berhasil tidaknya pemberantasan tuberkulosis di suatu daerah karena sumber penularan berasal dari penderita TB paru BTA positif dewasa. TB dewasa $90 \%$ merupakan reaktivasi tuberkulosis anak(endogeneous reinfection), dengan demikian tuberkulosis anak akan merupakan titik tolak sumber penularan dan TB manifest di hari kemudian ${ }^{5}$.

Proses kejadian penyakit $\mathrm{Tb}$ anak di masyarakat sangat kompleks dan melibatkan banyak variabel dimana berbagai variabel tersebut dikenal sebagai faktor risiko. Berbagai faktor risiko dalam mempengaruhi kejadian TB anak saling berkaitan satu sama lain dan identifikasi faktor risiko menentukan keberhasilan pengendaliannya ${ }^{9}$. Kebijakan memerlukan evidence yang dikenal sebagai evidence based policy, kalau evidence yang di lakukan kurang tepat, maka akan menyebabkan policy yang tidak tepat pula ${ }^{9,10}$. Kompleksitas peran faktor risiko mengindikasikan bahwa kebijakan pengendalian TB dan evidences harus memperhatikan kompleksitas penularan TB pada masyarakat. Namun demikian kebijakan pengendalian $\mathrm{Tb}$ hanya berfokus pada pengobatan
kasus(DOTS) $^{11}$ dan kegagalan pengobatan akan menyebabkan adanya penularan aktif kepada 'population at risk' terutama anak anak yang akan menumbuhkan cohort baru.

TB anak tidak pernah tergantung hanya kepada sebuah faktor penyebab melainkan dipengaruhi oleh sejumlah faktor dalam rangkaian proses sebab akibat dimana faktor risiko banyak yang bersifat laten atau untuk mengukurnya dibutuhkan variabel indikator, maka diperlukan model yang dapat menggambarkannya dan menganalisis kekuatan dari faktor-faktor tersebut secara simultan dan akhirnya dapat ditentukan prioritas masalah ${ }^{12-, 22}$. Dengan kata lain, diperlukan pendekatan baru terhadap analisis kejadian TB anak yang berbasis komunitas, bersifat kompleks dan mendasar.

Berdasarkan latar belakang tersebut, maka dapat dirumuskan masalah penelitian adalah bagaimanakah model jejaring kausalitas penularan TB anak yang cocok/sesuai (fit) dengan masalah yang ada dan adakah hubungan kausal antara berbagai variabel laten yang mempengaruhinya.

Tujuan yang hendak dicapai pada penelitian ini adalah mengetahui prevalensi TB anak pada anak yang tinggal serumah dengan penderita BTA positip dan mengembangkan model jejaring kausalitas penularannya yang cocok/sesuai(fit) dengan masalah yang ada serta mengetahui hubungan kausal antara berbagai faktor risikonya.

\section{METODE PENELITIAN}

\section{A. Desain Penelitian}

Menurut cara pendekatannya penelitian ini termasuk penelitian Crossectional yang bermaksud memotret hubungan variabel independen dan dependen secara simultan. Penggunaan desain Crossectional dikarenakan sesuai dengan masalah yang ada dan metoda penelitan terbaik adalah tergantung dari masalahnya ${ }^{44-49}$.

B. Populasi dan Sampel

Populasi adalah anak usia kurang dari 15 tahun yang hidup bersama dengan penderita TB Paru BTA(+) sedang sampel adalah anak yang tinggal serumah dengan penderita TB Paru BTA positip.

Besar Sampel untuk analisis dengan SEM membutuhkan sampel paling sedikit 5 kali jumlah variable indikator yang dibutuhkan ${ }^{18-22}$. Jumlah indikator 23 buah, maka jumlah sampel yang digunakan dalam penelitian adalah 184 responden (8 X 23) ditambah sampel cadangan 11 anak = 195 anak.

C. Bahan dan Alat

Data primer untuk membuat model penularan TB anak pada penelitian ini berupa data tentang status terinfeksinya anak terhadap TB dengan melakukan tes tuberkulin serta mendiagnosa gejala klinisnya kemudian dibuat skor ${ }^{5,50}$. Sedangan kondisi soial ekonomi, kondisi rumah 
tinggal, kondisi lingkungan, perilaku penderita BTA (+) dan kerentanan anak diperoleh dengan wawancara menggunakan kuesioner dan observasi $^{51,52}$.

Instrumen yang digunakan adalah kuesioner, lux meter, meteran, dan hygrometer. Sedangkan alat-alat yang dibutuhkan untuk uji Tuberkulin meliputi semprit tuberkulin (spuit 1 CC) , Jarum suntik no. 26 atau 27 dan tuberkulin.

D. Analisis data

Model yang digunakan dalam penelitian ini adalah model kausalitas atau hubungan pengaruh. Untuk menguji hipotesis yang diajukan maka teknik analisis data menggunakan SEM (Stuctural Equation Modeling) yang dioperasikan melalui program AMOS 18. Permodelan penelitian melalui SEM memungkinkan seorang peneliti dapat menjawab pertanyaan penelitian yang bersifat dimensional (yaitu mengukur apa indikator dari sebuah konsep) dan regresif (mengukur pengaruh atau derajad hubungan antara faktor yang telah diidentifikasikan dimensinya) ${ }^{18-22,53}$.

\section{III.HASIL PENELITIAN}

A. Infeksi TB Paru pada anak

Tabel 1 Hasil Tes Tuberkulin

\begin{tabular}{|c|c|c|c|}
\hline No & Luas Indurasi (mm) & Jumlah & $\%$ \\
\hline 1 & $<1$ & 36 & 33,08 \\
\hline 2 & $1-5$ & 30 & 17,09 \\
\hline 3 & $5-10$ & 35 & 20,00 \\
\hline 4 & $10-15$ & 39 & 21,00 \\
\hline 5 &.$>15$ & 55 & 7,20 \\
\hline & Jumlah & 195 & 100,00 \\
\hline
\end{tabular}

Sesuai dengan kriteria bahwa dinyatakan positip apabila luas indurasi lebih dari $15 \mathrm{~mm}$, maka dari tabel diatas terlihat bahwa subyek dinyatakan positip tuberkulin berjumlah 55 anak (28, 2\%), dinyatakan ragu-ragu $(10-15 \mathrm{~mm}): 39$ anak (20\%).

Dari hasil tes tuberkulin tersebut dan pemeriksaan terhadap status gizi, serta tandatanda lain didapatkan skor total seperti tabel sebagai berikut :

Tabel 2. Hasil diagnosa TB Anak berdasakan jumlah Skor

\begin{tabular}{clcc}
\hline No & Total Skor & Jumlah & Persen \\
\hline 1 & TB Anak $($ Skor $>6)$ & 76 & 39,0 \\
2 & Tidak Sakit $($ Skor $<6)$ & 119 & 61,0 \\
& Jumlah & 195 & 100,0 \\
\hline
\end{tabular}

Dari tabel terlihat yang menderita TB anak berdasarkan hasil skoring : $39 \%$ anak .

B. Hasil Analisis dengan Structural Equation Modelling (SEM)

1. Hasil Uji Model Pengukuran
Model pengukuran adalah bagian dari model yang diteliti dimana dalam analisis dengan SEM terdiri atas sebuah variabel laten (konstruk) dan beberapa variabel manifest (indikator) yang menjelaskan variable laten tersebut. Tujuan pengujian adalah untuk mengetahui seberapa tepat variable-variabel indikator tersebut dapat menjelaskan variable laten atau konstruk yang ada.

Dari hasil estimasi model pengukuran, maka diperoleh hasil bahwa terdapat 1 indikator(Indikator X63) tidak valid agar model memenuhi asumsi yang diperlukan. Dengan mengeluarkan indikator tersebut, maka model menjadi memenuhi asumsi yang diperlukan, di antaranya adalah p-value sebesar 0,098 > 0,05 dan RMSEA sebesar $0,026<0,08$ atau 0,05 . Parameter yang lain juga relatif memenuhi syarat yaitu sebagai berikut:

Tabel 3 Goodness of Fit Indices

\begin{tabular}{|l|c|c|c|}
\hline $\begin{array}{c}\text { Goodness of } \\
\text { fit index }\end{array}$ & Cut-off Value & Estimasi & Ket \\
\hline Chi-square $(\chi$ & $\begin{array}{c}\text { Diharapkan } \\
\text { kecil }\end{array}$ & 242,281 & Good \\
\hline $\begin{array}{l}\text { Significance } \\
\text { probability }\end{array}$ & $\geq 0,05$ & 0,098 & Good \\
\hline RMSEA & $\leq 0,08$ & 0,026 & Good \\
\hline GFI & $\geq 0,90$ & 0,891 & Marjinal \\
\hline AGFI & $\geq 0,90$ & 0,861 & Marjinal \\
\hline CMIN/DF & $\leq 3,00$ & 1,127 & Good \\
\hline TLI & $\geq 0,90$ & 0,892 & Marjinal \\
\hline CFI & $\geq 0,90$ & 0,908 & Good \\
\hline
\end{tabular}

Persyaratan lain, seperti jumlah sampel, asumsi normalitas, outliers atau multikolineritas telah memenuhi syarat, sehingga model dapat diinterpretasikan dan dinyatakan fit.

2. Hasil Uji Model Struktural

Setelah estimasi yang diperoleh dari model pengukuran diketahi bahwa model pengukuran memiliki kesesuaian model, serta konstruk yang digunakan memiliki reliabilitas dan validitas yang baik maka selanjutnya dilakukan analisis atas model stuktural yang diajukan.

Pengujian hipotesis dilakukan melalui pengamatan terhadap nilai C.R. atupun $p$ dari regression weight. Hipotesis diterima jika $\mathrm{p}$ bernilai di bawah 0,10 (10\%). Penggunaan $\alpha$ : $10 \%$ dikarenakan model yang relatif rumit, parameternya relatif luas serta skala pengukurannya juga sangat bervariasi. Dengan demikian digunakan toleransi sebesar 10\% yang lebih longgar, selain itu belum pernah dilakukan penelitian serupa untuk daerah yang 
sama. Hasil pengujian Structural Equation Model yang terdapat pada Tabel di bawah untuk menelaah lebih lanjut untuk menerima atau menolak hipotesis yang terdapat dalam penelitian

Hasil uji hubungan timbal balik (korelasi) antara variabel potensi menular penderita BTA positip (X1) dan sosialekonomi (X2) terdapat pada output sebagai berikut

Tabel 4. hubungan timbal balik antara variabel $\mathrm{X} 1$ dan X2

\begin{tabular}{|ll|ccccc|}
\hline & & Estimate & S.E. & C.R. & P & Label \\
\hline X1 & $<-->$ X2 & $\mathbf{. 3 8 1}$ & $\mathbf{. 0 8 2}$ & $\mathbf{4 . 6 6 4}$ & $* * *$ & par_19 \\
\hline
\end{tabular}

Sedangkan hasil uji pengaruh (regression Weigh) antar variabel independen dan antara variabel independen terhadap variabel dependen dapat terlihat pada tabel berikut : Tabel 5. Hasil analisis dengan Regression Weights

\begin{tabular}{|c|c|c|c|c|c|}
\hline & Estimate & S.E. & C.R. & $\mathrm{P}$ & Label \\
\hline X4 <---X2 & .136 & .077 & 1.773 & .076 & par_18 \\
\hline X5 <---X2 & .341 & .112 & 3.048 & .002 & par_20 \\
\hline X3<---X2 & .506 & .116 & 4.363 & $* * *$ & par_22 \\
\hline X6 <---X2 & -.085 & .086 & -.985 & .325 & par_21 \\
\hline$X 5<---X 4$ & .217 & .321 & .676 & .499 & par_23 \\
\hline X6 <---X3 & .025 & .075 & .340 & .734 & par_26 \\
\hline$<---X 1$ & .057 & .033 & 1.717 & .086 & par_16 \\
\hline$<---X 2$ & .081 & .046 & 1.764 & .078 & par_32 \\
\hline$<---X 3$ & .071 & .041 & 1.723 & .085 & par_25 \\
\hline$<---X 5$ & .118 & .038 & 3.111 & .002 & par_27 \\
\hline$<---X 6$ & .094 & .045 & 2.075 & .038 & par_29 \\
\hline
\end{tabular}

Dari tabel hasil uji hipotesis yang terdapat pada tabel 5.29 dan 5.30 diatas, dapat diketahui dari 12 hipotesis yang diajukan terdapat 9 hipotesis terbukti dan 3 hipotesis tidak terbukti.

a. Terdapat hubungan Timbal balik antara potensi menular penderita TB Paru BTA positip dengan sosial ekonomi.

Hasil uji korelasi pada table 5.29 diperoleh nilai $\mathrm{p}=0,001$ lebih kecil dari 0,05. Dengan demikian dapat disimpulkan bahwa hipotesis terbukti, yaitu terdapat hubungan timbal balik antara potensi menular penderita TB Paru BTA positip dengan sosial ekonomi.

b. Terdapat pengaruh sosial ekonomi terhadap risiko perilaku responden, kondisi rumah tinggal, kondisi lingkungan rumah, kerentanan anak dan kejadian TB paru anak

Dari hasil uji Regression Weight seperti terdapat pada tabel 5.30

1) Variabel sosial ekonomi dengan risiko perilaku menghasilkan nilai $\mathrm{p}=0,01$ memenuhi syarat $<0,05$. Dengan demikian dapat disimpulkan bahwa hipotesis terbukti, yaitu variabel sosial ekonomi ber-berpengaruh terhadap perilaku berisiko.

2) Variabel sosial ekonomi dengan kondisi rumah menghasilkan nilai $\mathrm{p}=$ 0,076 memenuhi syarat $<0,010$. Dengan demikian dapat disimpulkan bahwa hipotesis terbukti, yaitu variabel sosial ekonomi ber-berpengaruh terhadap kondisi rumah tinggal.

3) Variabel sosial ekonomi dengan kondisi lingkungan rumah menghasilkan nilai $\mathrm{p}=0,02$ memenuhi syarat $<0,05$. Dengan demikian dapat disimpulkan bahwa hipotesis terbukti, yaitu variabel sosial ekonomi berberpengaruh terhadap lingkungan rumah.

4) Variabel sosial ekonomi dengan kerentanan anak menghasilkan nilai $\mathrm{p}$ $=.325$ tidak memenuhi syarat >0,05. Dengan demikian dapat disimpulkan bahwa hipotesis tidak terbukti, yaitu variabel sosial ekonomi tidak berberpengaruh terhadap kerentanan anak.

5) Variabel sosial ekonomi dengan kejadian TB anak diperoleh nilai $\mathrm{p}=$ 0,078 memenuhi syarat $<0,010$. Dengan demikian dapat disimpulkan bahwa hipotesis terbukti, yaitu variabel sosial ekonomi berpengaruh terhadap kejadian TB anak

c. Terdapat pengaruh adanya potensi menular penderita BTA positip terhadap kondisi rumah tinggal dan kejadian TB anak.

Hasil pengujian parameter estimasi antara potensi menular penpenderita TB paru BTA positip dengan kejadian TB anak menghasilkan nilai $\mathrm{p}=0,086$ memenuhi syarat $<0,010$. Dengan demikian dapat disimpulkan bahwa hipotesis terbukti, yaitu variabel penderita TB paru BTA positip berpengaruh terhadap kejadian TB anak

d. Terdapat pengaruh kondisi rumah responden terhadap lingkungan rumah Hasil pengujian parameter estimasi yang didapat antara kondisi rumah dan lingkungan rumah menghasilkan nilai $\mathrm{p}=$ 0,676 tidak memenuhi syarat $>0,05$ maupun 0,010. Dengan demikian dapat disimpulkan hipotesis tidak terbukti, yaitu variabel kondisi rumah responden tidak berberpengaruh terhadap lingkungan rumah responden. 
e. Terdapat pengaruh risiko perilaku responden terhadap kerentanan anak dan kejadian TB paru anak

1) Hasil pengujian parameter estimasi yang didapat antara perilaku dan kerentanan menghasilkan nilai $\mathrm{p}=$ 0,340> 0,05 maupun 0,010. Dengan demikian dapat disimpulkan bahwa hipotesis tidak terbukti, yaitu variabel perilaku responden tidak berberpengaruh terhadap kerentanan anak responden

2) Hasil pengujian parameter estimasi yang didapat antara risiko perilaku terhadap kejadian TB anak menghasilkan nilai $\mathrm{p}=0,086$ memenuhi syarat $<0,010$. Dengan demikian dapat disimpulkan bahwa hipotesis terbukti, yaitu variabel risiko perilaku berpengaruh terhadap kejadian TB anak

f. Terdapat pengaruh kondisi lingkungan terhadap kejadian TB anak

Hasil pengujian parameter estimasi yang didapat antara konndisi lingkungan rumah terhadap kejadian TB anak menghasilkan nilai $\mathrm{p}=0,002$ memenuhi syarat $<0,05$. Dengan demikian dapat disimpulkan bahwa variabel lingkungan berpengaruh terhadap kejadian TB anak

g. Terdapat pengaruh kerentanan anak terhadap kejadian TB paru anak

Hasil pengujian parameter estimasi yang didapat antara kerentanan anak dengan kejadian TB anak menghasilkan nilai $\mathrm{p}=$ 0,038 memenuhi syarat $<0,05$. Dengan demikian dapat disimpulkan bahwa hipotesis terbukti, yaitu variabael kerentanan anak berpengaruh terhadap kejadian TB anak

\section{Analisis Pengaruh}

Tujuan analisis ini adalah untuk menganalisis kekuatan pengaruh antar variabel yang terdiri dari: analisis pengaruh langsung, tidak langsung, maupun analisis pengaruh total. Pengaruh langsung adalah koefisien dari semua garis dengan anak panah satu ujung. Pengaruh tidak langsung adalah pengaruh yang muncul melalui sebuah variabel antara. Pengaruh total adalah pengaruh dari berbagai hubungan. Hasil pengujian pengaruh langsung dinyatakan dalam Tabel 4,6, 4,7 dan 4,8 berikut ini:

a. Pengaruh Langsung

Tabel 6 Pengaruh langsung Variabel TB BTA (+) terhadap kejadian TB Anak

\begin{tabular}{cccccccc}
\hline & X2 & X1 & X4 & X5 & X3 & X6 & Y \\
\hline X4 &, 386 &, 155 &, 000 &, 000 &, 000 &, 000 &, 000 \\
X5 &, 371 &, 000 &, 083 &, 000 &, 000 &, 000 &, 000 \\
X3 &, 574 &, 000 &, 000 &, 000 &, 000 &, 000 &, 000 \\
X6 &,- 159 &, 085 &,- 033 &, 120 &, 042 &, 000 &, 000 \\
\hline
\end{tabular}

\begin{tabular}{cccccccc}
\hline & $\mathrm{X} 2$ & $\mathrm{X} 1$ & $\mathrm{X} 4$ & $\mathrm{X} 5$ & $\mathrm{X} 3$ & $\mathrm{X} 6$ & $\mathrm{Y}$ \\
\hline $\mathrm{Y}$ &, 308 & $\mathbf{2 0 8}$ &, 000 &, 410 &, 236 &, 189 &, 000 \\
\hline
\end{tabular}

Dari tabel 6 dapat dilihat bahwa pengaruh langsung variabel Sosial ekonomi terhadap kejadian TB Anak (Y) : 0,308 atau, variabel TB BTA (+) (X1) : 0,208, variabel lingkungan : 0,410 dan variabel keentanan 0,189

b. Pengaruh Tidak Langsung

Tabel 7 Pengaruh tidak langsung Variabel TB BTA $(+)$ terhadap kejadian TB Anak

\begin{tabular}{|c|c|c|c|c|c|c|c|}
\hline & X2 & X1 & X4 & X5 & X3 & X6 & Y \\
\hline $\mathrm{X} 4$ & 000, & 000, & 000, & 000, & ,000, & 000, & 000, \\
\hline X5 & 032, & 013, & 000, & 000, & ,000, & 000, & 000, \\
\hline X3 & 000, & 000, & 000, & 000, & 000 & 000, & 000, \\
\hline X6 & 060, & -,004 & 010, & 000, & 000, & 000, & 000, \\
\hline Y & 282 & 021 & 030, & 023, & 008, & ,000, & 000, \\
\hline
\end{tabular}

Dari tabel 7 dapat dilihat bahwa pengaruh tidak langsung variabel Sosial ekkonomi (X2) ke TB anak (Y) : 0,282, TB BTA (+) (X1) : 0,021, variabel perumahan : 0,030 dan variabel perilaku : 0,008.

c. Pengaruh Total

Tabel 8 Pengaruh Total Variabel TB BTA (+) terhadap kejadian TB Anak

\begin{tabular}{cccccccc}
\hline & X2 & X1 & X4 & X5 & X3 & X6 & Y \\
\hline X4 &, 386 &, 155 &, 000 &, 000 &, 000 &, 000 &, 000 \\
X5 &, 403 &, 013 &, 083 &, 000 &, 000 &, 000 &, 000 \\
X3 &, 574 &, 000 &, 000 &, 000 &, 000 &, 000 &, 000 \\
X6 &,- 099 &, 081 &,- 023 &, 120 &, 042 &, 000 &, 000 \\
Y &, 590 &, 229 &, 030 &, 433 &, 244 &, 189 &, 000 \\
\hline
\end{tabular}

Dari tabel terlihat pengaruh total terhadap kejadian TB anak (Y), terbesar adalah variabel sosial ekonomi (X2): 0,590 (.308 $+.282: 0,590)$, kemudian diikuti berturut turut Variabel Lingkungan(X5) : 0, 433, variabel perilaku (X3) : 0,244, variabel TB $\mathrm{BTA}(+)(\mathrm{X} 1)$ : 0,229 variabel kondisi rumah (X4) : 0,30, , dan variabel kerentanan 0,189.

\section{IV.PEMBAHASAN}

Hasil penelitian didapatkan bahwa subyek dinyatakan tuberkulin positip(>15 mm) berjumlah 55 anak(28, 2\%) yang berarti prevalensi anak dengan tuberkulin positip : 28,2 \%, sedangkan hasil perhitungan menggunakan sistim skoring untuk mendiagnosa TB anak didapatkan subyek yang menderita TB anak(skor > 6) : 76 anak(39 \%), dengan demikian dari hasil penelitian menunjukkan prevalensi TB anak pada anak atau keluarga penderita TB BTA positip sebesar $39 \%$.

Dengan hasil penelitian ini dapat menjawab mengapa kohort baru atau penyakit TB selalu timbul atau dengan kata lain berbagai usaha yang telah dilakukan ternyata belum dapat menurunkan insiden TB paru, dikarenakan terjadinya penularan dari penderita BTA positip ke anak yang tinggal serumah dan tuberkulosis anak akan merupakan titik tolak 
sumber penularan dan TB manifest di hari kemudian 4,5 .

Proses kejadian penyakit Tb anak di masyarakat melibatkan banyak faktor risiko dan berbagai faktor risiko tersebut saling berkaitan antara satu dengan lainnya serta telah banyak alat analisis multi dimensi yang telah dikenal luas. Namun semua analisis yang telah digunakan tersebut belum mampu melakukan analisis kausalitas berjenjang dan simultan. Kelemahan utama dari alat analisis multivariat dimaksud, terletak pada keterbatasannya yang hanya dapat menganalisis satu hubungan pada satu waktu. ${ }^{18-}$ 22 .

SEM merupakan sebuah jawaban untuk mencari pemecahan masalah terhadap faktor risiko TB anak yang sangat komplek serta antar variabelnya saling berhubungan bahkan sifat hubungannya timbal balik dan SEM merupakan teknik analisis multivariat yang dikembangkan guna menutupi keterbatasan yang dimiliki oleh model-model analisis sebelumnya yang telah digunakan secara luas.

Hasil analisis pengukuran terhadap model kausal penularan TB Anak dengan confirmatory factor analysis(CFA) dapat diketahui bahwa model dinyatakan cocok/sesuai(fit). Hal tersebut didasarkan hasil analisis parameter dibandingkan dengan indeks goodness of fit yang telah memenuhi kriteria yang disyaratkan. Model yang layak merupakan petunjuk adanya kecocokan model dengan teori substansif yang kuat, dan dapat menjadi penjelas yang masuk akal untuk menjelaskan data yang ada.

Hasil uji hipotesis diketahui dari 12 hipotesis yang diajukan terdapat 9 hipotesis terbukti dan 3 hipotesis tidak terbukti dan secara ringkas dapat dijelaskan sebagai berikut :

\section{A. Hubungan Timbal balik antara sosial ekonomi} dengan kejadian TB Paru

Menurut WHO (2003), 90\% penderita TB paru di dunia menyerang kelompok dengan ekonomi lemah atau miskin dan hubungan antara kemiskinan dengan TB paru bersifat timbal balik, dimana TB paru merupakan penyebab kemiskinan dan karena miskin maka mereka menderita TB paru $^{59}$. Kondisi ekonomi itu sendiri mungkin tidak hanya berhubungan secara langsung, namun dapat merupakan penyebab tidak langsung seperti adanya kondisi gizi memburuk, serta perumahan yang tidak sehat, dan akses terhadap pelayanan kesehatan juga menurun.

Temuan penelitian ini sesuai dengan hasil Riskesdas $2007^{60}$, yang menemukan prevalensi TB paru empat kali lebih tinggi pada pendidikan rendah dibandingkan pendidikan tinggi. Hasil tersebut juga tidak berbeda jauh dengan survey prevalensi di Banten distribusinya relatif merata di ke-5 kuintil. Di DKI Jakarta justru sebaliknya, ditemukan lebih banyak pada kelompok masyarakat berpenghasilan menengah ke atas (kuintil 4-5) ${ }^{61}$.
B. Pengaruh sosial ekonomi terhadap risiko perilaku responden, kondisi rumah tinggal, kondisi lingkungan rumah, kerentanan anak dan kejadian TB anak

1. Pengaruh Sosial ekonomi terhadap perilaku berisiko responden.

Berpengaruhnya kondisi sosial ekonomi terhadap perilaku seseorang sesuai dengan asumsi yang mengatakan bahwa seseorang akan bertindak atau berperilaku sesuai dengan kepedulian terhadap masalah yang ada. Kepedulian berperilaku sehat memiliki hubungan dengan kondisi soaialekonomi yang merupakan kebutuhan paling dasar karena perilaku sehat bersifat kontekstual dan hal itu sesuai dengan kondisi sosial ekonomi yang kontekstual pula. Mereka yang peduli terhadap terjadinya penularan TB paru melalui kondisi lingkungannya akan melakukan tindakan dalam pengendalian penyakit TB paru yaitu dengan cara pencegahan penyebaran dan penularan penyakit sebagai upaya agar penderita tidak menularkan kepada orang lain dan meningkatkan derajat kesehatan pribadi.

2. Pengaruh Sosial ekonomi terhadap kondisi rumah responden

Penduduk miskin biasanya mengeluarkan porsi yang lebih besar pengeluaran rumahtangganya untuk makanan (dari total pengeluaran rumah-tangga) sehingga mereka tidak sempat untuk memikirkan kondisi rumahnya.Kehidupan sosial ekonomi adalah suatu keadaan sosial ekonomi masyarakat yang menggunakan indikator pendidikan, pekerjaan dan penghasilan/pengeluaran sebagai tolak ukur.

Pendidikan merupakan salah satu unsur penting yang dapat memengaruhi keadaan keluarga karena dengan tingkat pendidikan yang lebih tinggi diharapkan pengetahuan atau informasi tentang perumahan yang sehat akan lebih baik. Pengetahuan kesehatan akan berpengaruh kepada perilaku seseorang sebagai hasil jangka menengah dari pendidikan yang diperoleh. Perilaku kesehatan akan berpengaruh pada meningkatnya indikator kesehatan masyarakat sebagai hasil dari pendidikan kesehatan.

3. Pengaruh Sosial ekonomi terhadap lingkungan rumah responden.

Asumsi lama yang mengidentikkan kepedulian social ekonomi dengan kondisi lingkungan rumahnya berawal dari teori yang dikemukakan oleh Maslow (1970) mengenai hierarchy of needs ${ }^{62}$. Dia berasumsi bahwa kepedulian terhadap kualitas lingkungan merupakan sesuatu yang mewah dan hanya bisa dinikmati setelah kebutuhan dasar terpenuhi, seperti makanan, tempat tinggal, dan keamanan finansial. Kemudian, argumen 
lain yang mendukung kepedulian lingkungan hanya ada di kalangan atas juga disampaikan oleh Morrison (1972), menurutnya masyarakat kelas bawah hanya memiliki pengalaman lingkungan yang buruk sehingga mereka tidak peduli dan terbiasa dengan tempat tinggal, tempat kerja, dan tempat bermain yang tercemar. Hal tersebut berbeda dengan mereka yang berada di kalangan menengah dan atas, kalangan ini telah memiliki pengalaman akan kualitas lingkungan yang baik dan menyenangkan sehingga berdampak pada kepedulian akan lingkungan tempat tinggalnya

Mereka yang berasal dari status sosial ekonomi menengah dan atas bisa peduli terhadap lingkungan karena telah terbebas dari tekanan akan kebutuhan dasar. Nilai-nilai post-materialist punya pengaruh akan terbentuknya kepedulian lingkungan dan hanya berlaku untuk kalangan ini. Jika dikaitkan dengan pengalaman (experience), kalangan menengah dan atas relatif telah merasakan lingkungan yang nyaman dan sehat sehingga ada usaha untuk tetap menjaga lingkungan seperti itu. Apabila lingkungan yang tadinya nyaman dan sehat itu terganggu dengan munculnya beragam masalah lingkungan maka mereka akan bergerak untuk peduli. Kepedulian itu timbul karena adanya keinginan untuk kembali lagi pada lingkungan terdahulu yang nyaman dan sehat.

4. Pengaruh sosial ekonomi terhadap kerentanan anak.

Kerentanan adalah keadaan di mana pejamu mempunyai kondisi yang mudah dipengaruhi/berinteraksi dengan unsur penyebab sehingga memungkinkan timbulnya penyakit dan kerentanan sangat berpengaruh dalam hasil akhir suatu proses kejadian penyakit, apakah proses tersebut akan berakhir sebagai penderita, meninggal, atau tidak ada perubahan yang jelas. Dengan demikian, peranan kerentanan individu yang berbeda dalam masyarakat dapat menimbulkan keadaan yang sering disebut dengan fenomena Gunung es.

Aspek sosial ekonomi berhubungan dengen kerentanan, karena sosial ekonomi menyebabkan anak kurang gizi dan faktor gizi kurang meningkatkan menyebabkan kerentanan terhadap penyakit rendah. Hasil penelitian Dudeng, dkk (2006) ${ }^{63}$ menyatakan bahwa anak dengan status gizi tidak baik mempunyai risiko 3,28 kali lebih besar menderita Tuberkulosis dibanding anak dengan status gizi baik.

Gizi mempunyai peran besar dalam daur kehidupan. Kebutuhan akan nutrient berubah sepanjang daur kehidupan, dan ini terkait dengan pertumbuhan dan perkembangan masing-masing tahap kehidupan. Berkaitan dengan hal tersebut nutrient yang tidak adekuat mempengaruhi daya tahan tubuh seseorang yang berkibat menurunnya antibody sehingga penyakit mudah menyerang, salah satunya yang berkaitan erat yaitu penyakit paru $^{30}$.

Tidak berpengaruhnya sosial ekonomi terhadap kerentanan pada penelitian ini dikarenakan kerentanan yang diukur meliputi umur, jenis kelamin dan status iminisasi.

5. Pengaruh Sosial ekonomi terhadap kejadian TB anak

Penyakit terjadi bila ketidak seimbangan antara faktor lingkungan, agen (kuman) dan host (Individu). Bila daya tahan host baik maka bila terjadi suatu invasi oleh agen (kuman) tubuh akan mampu mengeliminir. Demikian pula yang terjadi bila seorang menderita infeksi oleh mikobakterium tuberkulosis.

Sembilan puluh persen infeksi oleh mikobakterium tuberkulosa akan diikuti oleh "self limited" karena pada mereka yang mempunyai status nutrisi yang baik respon imun seluler cukup untuk mengontrol multiplikasi baksil. Sedangkan pada mereka yang sistim imun selulernya tidak berfungsi dengan baik lebih kurang $10 \%$ akan terjadi progresitifitas TB paru primer. Yang dapat ditemui pada dewasa dan sebagian kecil pada anak usia kurang 5 tahun serta pada penderita immonocompromised ${ }^{64}$.

Penyakit tuberkulosis merupakan suatu penyakit granuloma kronis. Mikobakterium tuberkulosis adalah salah satu penyebab yang berasal dari kelompok patogen, dan mempunyai kemampuan memperbanyak diri baik didalam maupun diluar makrofag. Perkembangan infeksi tergantung pada keseimbangan antara kemampuan makrofag untuk meng-hancurkan baksil ini. Dan baksil dapat bertahan atas kemampuan bakteriosid dari makrofag karena adanya berbagai macam enzim.

Pada penderita dengan status malnutrisi jelek (malnutrisi kronik) bila ada infeksi oleh mikobakterium tuberkulosa, limfosit tidak dapat memberikan signalnya kepada makrofag (sehingga makrofag tidak aktif) yang mengakibatkan penyakit menjadi progresif. Dengan demikian hitung limfosit total dapat digunakan untuk mengetahui status immunologi penderita. Infeksi merupakan penyebab kematian utama pada malnutrisi berat $^{64-66}$.

C. Pengaruh adanya potensi menular penderita BTA positip terhadap kejadian TB anak 
Terjadinya penyakit TB paru pada manusia dimulai dari bibit penyakit yang berasal dari sumbernya (Simpul 1) yaitu bakteri Mycobacterium tuberculosis selanjutnya media penularannya melalui media transmisi udara dalam rumah (Simpul 2) yang dipengaruhi faktor risiko lingkungan, bakteri Mycobacterium tuberculosis akan masuk ke dalam tubuh manusia (Simpul 3) yang rentan, hingga akhirnya dapat menyebabkan penyakit TB paru ${ }^{9,10}$.

Sumber penularan penyakit TBC adalah penderita TB BTA positif. Pada waktu batuk atau bersin, penderita menyebarkan kuman ke udara dalam bentuk percikan dahak (droplet nuclei), dimana sekali batuk dapat menghasilkan sekitar 3000 percikan dahak. Bakteri ini bila sering masuk dan terkumpul di dalam paru-paru akan berkembang biak menjadi banyak (terutama pada orang dengan daya tahan tubuh yang rendah), dan dapat menyebar melalui pembuluh darah atau kelenjar getah bening. Oleh sebab itulah infeksi TBC dapat menginfeksi hampir seluruh organ tubuh seperti: paru-paru, otak, ginjal, saluran pencernaan, tulang, kelenjar getah bening, dan lain-lain, meskipun demikian organ tubuh yang paling sering terkena yaitu paruparu $^{8},{ }^{50.67}$.

D. Pengaruh kondisi rumah terhadap lingkungan rumah

Kualitas udara dalam ruangan dapat dipengaruhi oleh banyak faktor, baik yang berasal dari dalam gedung sendiri maupun dari luar gedung. Beberapa kondisi yang potensial menyebabkan udara didalam gedung tidak baik adalah kepadatan manusia, bahan material dan dekorasi interior, sistem ventilasi dan produk produk rumah tangga sedangkan faktor di luar gedung yang paling berperan adalah kondisi pencahayaan karena pencahayaan akan berpengaruh terhadap suhu udara dan kelembaban udara dalam ruangan ${ }^{9,10}$.

Menurut Roger (1990), faktor-faktor yang dapat mempengararuhi kualitas pencahayaan antara lain sifat cahaya dan sifat cahaya ditentukan oleh dua hal, yaitu kuantitas atau banyaknya cahaya yang jatuh pada suatu permukaan yang menyebabkan terangnya permukaan tersebut serta kualitas atau sifat cahaya yang menyangkut warna, arah cahaya dan difusi cahaya serta jenis dan tingkat kesilauan. Selain itu Ching (1987) juga mengatakan bahwa ketinggian dan kualitas permukaan langit-langit akan mempengaruhi derajat cahaya di dalam ruang.

Kelembaban udara dalam rumah berkaitan dengan ventilasi yang tidak memenuhi syarat kesehatan. Ventilasi sangat menentukan kualitas udara dalam rumah karena dengan ventilasi yang cukup akan memungkinkan lancarnya sirkulasi udara dalam rumah dan masuknya sinar matahari serta akan mempengaruhi suhu udara dalam rumah $^{9,10}$

E. Pengaruh risiko perilaku terhadap kerentanan anak dan kejadian TB paru anak

1. Pengaruh risiko perilaku terhadap kerentanan anak responden.

Kerentanan adalah keadaan di mana pejamu mempunyai kondisi yang mudah dipengaruhi/berinteraksi dengan unsur penyebab sehingga memungkinkan timbulnya penyakit. Peranan kerentanan sangat berpengaruh dalam hasil akhir suatu proses kejadian penyakit, apakah proses tersebut akan berakhir sebagai penderita, meninggal, atau tidak ada perubahan yang jelas. Dengan demikian, peranan kerentanan individu yang berbeda dalam masyarakat dapat menimbulkan keadaan yang sering disebut dengan "fenomena Gunung es" (iceberg phenomena).

Karakteristik individu dapat mempengaruhi kerentanan seseorang. Umur, jenis kelamin, status kesehatan, pekerjaan, pendidikan, dan mobilitas penduduk mempengaruhi kerentanan seseorang. Sedangkan perilaku meludah penderita, perilaku tidur, merokok pola asuh anak dapat memperkecil penular TB sehingga perilaku tidak mempengaruhi terhadap kerentanan ${ }^{68,69}$.

2. Pengaruh risiko perilaku terhadap kejadian TB anak

Perilaku yang berkaitan dengan penularan TB paru antara lain meludah di sembarang tempat. Perilaku tersebut berisiko untuk menularkan kepada orang lain dimana penderita TB paru dewasa sering kurang memperhatikan kesehatan dirinya dan baru menyadarinya setelah kondisi tubuh melemah atau batuk mengeluarkan darah dan sesak nafas. Kondisi tersebut padahal merupakan kondisi yang sangat infeksius sehingga apabila penderita meludah maka ludah yang mengandung kuman TB paru akan tersebar di lingkungan sekitarnya ${ }^{40}$.

Perilaku penderita TB paru BTA positif yang juga berisiko menularkan penyakit TB Paru adalah tidur bersama-sama dalam satu tempat tidur/kamar dengan istri, suami anak dan anggota keluarga lainnya dapat menularkan penyakit TB paru sebanyak 68\%. Selama sakitnya penderita TB paru dengan sputum BTA positif bisa menularkan berpuluh-puluh orang sampai beratus-ratus orang tetapi bisa juga hanya 1-2 orang saja atau nihil. Untuk mem-pertahankan keadaan seimbang atau prevalensi tetap sama. Seorang penderita TB paru dengan BTA positif hanya perlu menulari 20 orang sehat, dan kemudian di antaranya satu orang akan menjadi 
pengganti sebagai sumber penularan baru setelah lama menjadi sembuh atau mati ${ }^{68-70}$.

Perilaku merokok juga meningkatkan resiko terinfeksi penyakit TB Paru. Asap rokok mengandung bahan kimia yang memiliki efek proinflamasi dan imunosupresif pada sistem imun saluran pernapasan, sehingga dapat meningkatkan risiko infeksi $\mathrm{M}$. tuberculosis. Baik perokok, mantan perokok, dan perokok pasif dapat meningkatkan risiko terinfeksi kuman M. tuberculosis ${ }^{26,27}$.

$\operatorname{Lin}^{129}$, menyatakan bukti hubungan antara kebiasaan merokok, perokok pasif, dan polusi udara di dalam ruangan dari kayu bakar dan batu bara terhadap risiko infeksi, penyakit, dan kematian akibat TBC. Dari sekitar 100 orang yang diteliti, ditemukan yang merokok tembakau dan menderita TBC sebanyak 33 orang, perokok pasif dan menderita TBC 5 orang, dan yang terkena polusi udara dan menderita TBC 5 orang $^{26}$.

Studi pada pekerja perkebunan di California, AS, menemukan hubungan bermakna antara prevalensi reaktivitas tes tuberkulin dan kebiasaan merokok. Pada bekas perokok, hubungan ini lebih kuat daripada mereka yang masih merokok. Data lain menunjukkan hubungan antara kebiasaan merokok dengan tuberkulosis aktif, hasilnya hanya bermakna pada mereka yang telah merokok lebih dari 20 tahun ${ }^{26}$. Di AS, para perokok yang telah merokok 20 tahun atau lebih ternyata 2,6 kali lebih sering menderita TBC daripada yang tidak merokok. Kebiasaan merokok meningkatkan mortalitas akibat TBC sebesar 2,8 kali.

Kaitan rokok dan TBC dapat dijelaskan bahwa dengan racun yang dibawanya, rokok merusak mekanisme pertahanan paru-paru. Bulu getar dan alat lain dalam paru-paru yang berfungsi menahan infeksi rusak akibat asap rokok. Asap rokok meningkatkan tahanan pelan napas (airway resistance). Akibatnya, pembuluh darah di paru mudah bocor. Juga merusak sel pemakan bakteri pengganggu dan menurunkan respon terhadap antigen, sehingga bila benda asing masuk ke dalam paru-paru, tidak ada pendeteksinya ${ }^{26}$.

Pola asuh yang diukur pada penelitian ini adalah pola asuh yang berkaitan dengan pencegahan penularan TB Paru yang meliputi Pola Asuh Makan (PAM) dan Pola Asuh Kesehatan (PAK) dengan pertimbangan bahwa PAM dan PAK berkaitan erat dengan konsumsi, status gizi dan status kesehatan Balita ${ }^{29}$. Pengukuran PAM antara lain pemberian ASI, pemberian makanan pendamping ASI dan makanan orang dewasa. Sedangkan pengukuran PAK meliputi
Imunisasi BCG, Kapsul Vitamin A dosis tinggi, penimbangan dan Hygiene Pribadi

Merujuk pada hasil penelitian dapat dijelaskan bahwa semakin baik pola asuh semakin anak tidak terkena TB. Hal ini sejalan dengan penelitian berkaitan dengan status gizi bahwa dengan adanya pola asuh yang baik utamanya asuhan gizi maka status gizi akan semakin baik. Pola pengasuhan yang diberikan ibu pada anak berhubungan dengan keadaan kesehatan (baik fisik maupun mental), status gizi, pendidikan, pengetahuan dan keterampilan, peran dalam keluarga dan adat kebiasaan dari ibu ${ }^{27}$.

\section{F. Pengaruh kondisi lingkungan rumah terhadap kejadian TB anak}

Hasil beberapa penelitian terdahulu dengan rancangan case control diketahui bahwa penghuni rumah yang pencahayaan-nya tidak memenuhi syarat akan 2,5 kali terkena TBC paru dibanding penghuni yang pencahayaan rumahnya memenuhi persyaratan $^{71}$.

Cahaya matahari sangat penting karena dapat membunuh bakteri patogen di dalam rumah misalnya baksil TBC. Pencahayaan alami yang langsung ke dalam ruangan rumah dapat mengurangi terjadinya penularan penyakit tuberkulosis paru, karena cahaya ultra violet dari sinar matahari yang masuk ke dalam ruangan dapat membunuh kuman mycobacterium tuberculosis. Cahaya matahari mempunyai daya untuk membunuh bakteri, minimal masuk 60 lux dengan syarat tidak menyilaukan ${ }^{10}$.

Cahaya matahari cukup, tidak lebih dan tidak kurang, dimana cahaya matahari ini dapat diperoleh dari ventilasi maupun jendela/genting kaca. Suhu udara yang ideal dalam rumah antara $18-30^{\circ} \mathrm{C}$. Suhu optimal pertumbuhan bakteri sangat bervariasi, Mycobacterium tuberculosis tumbuh optimal pada suhu $37^{\circ} \mathrm{C}$. Paparan sinar matahari selama 5 menit dapat membunuh Mycobacterium tuberculosis. Bakteri tahan hidup pada tempat gelap, sehingga perkembangbiakan bakteri lebih banyak di rumah yang gelap ${ }^{9,10}$

Kelembaban merupakan sarana yang baik untuk pertumbuhan mycobacterium tuberculosis dan syarat kelembaban di dalam rumah adalah 4070\%. Sebuah penelitian di Kota Bogor menunjukan, penghuni rumah yang mempunyai kelembaban ruang keluarga lebih besar dari 60\% berisiko terkena TB paru 10,7 kali lebih tinggi dibandingkan penghuni rumah yang mempunyai kelembaban ruang keluarga kurang dari 60\% (Mulyadi, 2003). Penelitian Yuniati membuktikan bahwa penduduk yang tinggal dengan kelembaban $<40 \%$ dan $>70 \%$ berisiko terkena penyakit tuberkulosis paru 4,68 kali dibandingkan dengan penduduk yang tinggal pada perumahan yang memiliki kelembaban antara 40\% $70 \%{ }^{36,39,41}$. 
Kuman tuberkulosis dapat hidup baik pada lingkungan yang lembab, hal ini dikarenakan air membentuk lebih dari 80\% volume sel bakteri dan air merupakan hal yang essensial untuk pertumbuhan dan kelangsungan hidup, sehingga kuman dapat bertahan hidup pada tempat sejuk, lembab dan gelap tanpa sinar matahari sampai bertahun-tahun lamanya. Pertumbuhan bakteri memerlukan kelembaban yang tinggi yaitu diatas 85\%. Bakteri merupakan mikroorganisme yang suka pada lingkungan basah, bahkan dapat hidup di air. Tetapi bila air tertutup rapat tidak bisa tumbuh subur karena kekurangan udara $^{41,42}$.

G. Pengaruh kerentanan anak terhadap kejadian TB paru anak

Peranan faktor kerentanan sangat penting dalam epidemiologi karena faktor kerentanan dan keadaan kekebalan masyarakat serta sifat penyakit dalam masyarakat selalu diperhitungkan dalam setiap kegiatan epidemiologis. Kedua faktor tersebut sangat erat hubungannya dengan faktor risiko yakni tingkat/besarnya risiko untuk mengalami proses penyakit atau untuk menjadi sakit.

Manifestasi klinis dan patologis infeksi tuberkulosis dan kerentanan penderita akibat ketidak sempurnaan reaksi ketahanan tubuh. Penderita yang tidak mempunyai ketahanan tubuh (immune deficency) atau yang mengalami gangguan hambatan pengangkutan ketahanan tubuh (immune insufiency) mengakibatkan sel makrofak tidak berdaya memusnahkan kuman. Bayi dan anak kecil mempunyai daya tahan tubuh yang lemah, anak kecil mempunyai lebih sedikit kekebalan tubuh dibanding anak yang lebih tua. Makin muda umur anak makin rentan ia terhadap serangan bibit penyakit ${ }^{72}$.

\section{SIMPULAN DAN SARAN}

Prevalensi TB anak pada anak keluarga penderita TB BTA positip sebesar $39 \%$ merupakan penemuan baru yang dapat menjawab mengapa kohort baru penyakit TB paru selalu timbul atau dengan kata lain berbagai usaha yang telah dilakukan ternyata belum dapat menurunkan insiden TB paru, beban penyakit di masyarakat masih tinggi dan Indonesia menduduki urutan ke 4 dunia.

Hasil penelitian juga dapat membuktikan kerangka konsep baru yang menggambarkan kompleksitas faktor risiko yang mempengaruhi kejadian TB anak dalam suatu jejaring sebab akibat. Berdasarkan kerangka teoritis penelitian dengan kerangka konsep yang telah di uji kesesuaian modelnya melalui alat analisis Struktural Equation Model , maka model kausal jejaring penularan Tb anak melalui dimensi vaiabel potensi penularan penderita BTA positip, sosial ekonomi, perilaku, kondisi rumah, lingkungan dan kerentanan anak dan dampaknya terhadap kejadian TB anak dapat dinyatakan tepat atau $\operatorname{cocok}(f i t)$. Hasil penelitian ini secara umum memperkuat konsep Beaglehole (1997) tentang penyebab penyakit TB paru dan mempertegas model-model penularan penyaki pada segitiga epidemiologi, jaring-jaring sebab akibat, dan teori simpul.

Hasil analisis Structural Model dengan regression weight untuk melihat hubungan kausalitas dari 12 hipotesis yang dibangun terdapat 9 hipotesis terbukti dan 3 hipotesis tidak terbukti. Hipotesis yang terbukti meliputi:

1. Terdapat hubungan Timbal balik antara potensi menular penderita TB Paru BTA positip dengan sosial ekonomi

2. Terdapat pengaruh sosial ekonomi terhadap perilaku responden,

3. Terdapat pengaruh sosial ekonomi terhadap kondisi rumah tinggal,

4. Terdapat pengaruh sosial ekonomi terhadap kondisi lingkungan rumah,

5. Terdapat pengaruh sosial ekonomi terhadap kejadian TB anak

6. Terdapat pengaruh adanya potensi menular penderita BTA positip terhadap kejadian TB anak

7. Terdapat pengaruh risiko perilaku tidak sehat terhadap kejadian TB anak.

8. Terdapat pengaruh kondisi lingkungan rumah terhadap kejadian TB anak.

9. Terdapat pengaruh kerentanan anak terhadap kejadian TB anak.

Hipotesis yang tidak terbukti

1. Tidak ada pengaruh sosial ekonomi terhadap kerentanan anak

2. Tidak ada pengaruh kondisi rumah responden terhadap lingkungan rumah

3. Tidak ada pengaruh risiko perilaku tidak sehat terhadap kerentanan anak

Secara ringkas saran-saran yang dapat diberikan kepada manajerial dalam hal ini Dinas Kesehatan Kabupaten Banyumas dalam upaya mencegah kejadian TB Anak.

1. Tes kulit tuberkulin kepada anak keluarga penderita TB Paru BTA (+) perlu dilakukan secara periodik untuk mengetahui adanya paparan kuman TB pada anak.

2. Dinas Kesehatan Kabupaten Banyumas melakukan advokasi yang lebih sering untuk meningkatkan kepedulian Pemda. dan advokasi disertai dengan data atau informasi yang baru tentang pencapaian program penanggulangan TB lebih spesifik untuk meyakinkan para pengambil keputusan anggaran.

3. Kordinasi lintas sektor dengan pemerintah kecamatan dan desa, tokoh masyarakat, PKK, dan kader posyandu agar secara bersama-sama mendorong peran serta masyarakat terutama dalam meningkatkan kondisi kesehatan rumahnya

4. Petugas program Pemberantasan Penyakit TB paru meningkatkan koordinasi lintas program dengan petugas sanitarian puskesmas untuk 
melakukan inspeksi sanitasi rumah penderita TB paru.

5. Model perlu di ujicoba di wilayah lain, karena penelitian hanya menguji model jejaring penularan TB anak di Kabupaten Banyumas. Dengan demikian hasil dan implikasi manajerial dalam penelitian ini mungkin tidak sepenuhnya akurat bila diterapkan pada daerah lain karena setiap daerah dan individu mempunyai karakteristik, perilaku dan lingkungan yang berbeda.

\section{DAFTAR PUSTAKA}

1. World Health Organization. Indonesia TB Country Profile. Available from http:// www.who.int/tb/publications/global_report /en/ global tb report 2013

2. World Health Organization. Global Tuberculosis Control: WHO Report 2012. Available from www.who.int/tb/publications/ global_report/ I10665/75938/978924156 450 eng.pdf.

3. Kemenkes RI. 2011a. Strategi Nasional Pengendalian TB Di Indonesia 2010-2014. Kemenkes RI, Jakarta.

4. 2011b. Tuberkulosis Masalah Kesehatan Dunia. http:www.bppsdmk.depkes.go.id. Diakses tanggal 15 Juli 2011.

5. Kemenkes R.I, 2013. Petunjuk Teknis Manajemen TB Anak. Direktorat Jenderal Pengendalian Penyakit dan Penyehatan Lingkungan

6. Dinas Kesehatan Kabupaten Banyumas 2012. Laporan Program P2 TB Paru. Banyumas.

7. Departemen Kesehatan RI, 2007. Diagnosa dan Tata Laksanan Tuberkulosis Anak. Kelompok Kerja TB Anak Depkes - IDAI.

8. Kartasasmita, 2009. Epidemiologi Tuberculosis, Sari Pediatri, Vol 11 NO. 2. Agustus 2009.

9. Achmadi, F. 2008. Manajemen Penyakit Berbasis Wilayah. Buku Kompas, Jakarta.

10. Achmadi, F. 2012. Manajemen Penyakit Berbasis Wilayah. Edisi revisi. Buku Kompas, Jakarta.

11. Abdul Manaf dkk, 2008, Pedoman Nasional Penanggulangan Tuberkulosis, Depkes RI, Jakarata.
12. Santoso S, 2011. Stuktural Equation Modelling(SEM) Konsep dan Aplikasi dengan Amos 18, Elex Media Komputindo, Jakarta.

13. Wijanto SH, 2008. Structural Equation Modeling dengan Lisrel 8.8. Graha Ilmu. Jakarta

14. Ferdinand A, 2002. Struktural Equation Modeling dalam Penelitian Manajemen Edisi 2. Semarang FE Undip.

15. Widarjono A, 2010. Analisis Statistika Multivariat Terapan. Sekolah Tinggi Ilmu Manajemen YKPN. Yogjakarta

16. Kershaw T. Introduction to Structural Equation Modeling for HIV Prevention Research. Social Behavioral Sciences Program Epidemiology and Public Health Yale University

17. Jogiyanto, 2011. Konsep dan Aplikasi Structural Equation Modeling Berbasis Varian Dalam Penelitian Bisnis. UPP STIM YKPN. Yogyakarta

18. Narimawati U, 2007. Structural Equation Model dalam Riset Ekonomi. Gaya Media. Yogyakarta.

19. Wang P. 2007. Structural Equation Modeling And Its Applications in Health Research.http://www.nlcahr.mun.ca/resear ch/affinity/quantitative/QAG_SEM__Pet er_Wang.pdf. Diakses tanggal 23 Maret 2011

20. Jihan S, 2007. Pemodelan Persamaan Struktural pada Derajat Kesehatan dengan Moderasi Infrastruktur (Studi kasus di Propinsi Jawa Timur, Susenas 2007). Jurnal Teknik Pomits Vol. 1, No. 1, (2012) 1-6. Available http://digilib.its.ac.id/public/ITSUndergraduate-12362-Paper.pdf

21. Cheah WL at all, 2010. A structural equation model of the determinants of malnutrition among children in rural Kelantan, Malaysia. Universiti Malaysia Sarawak, Sarawak, Malaysia. Available from: http://www.rrh.org.au

22. Grahanintyas dkk, 2008. Pendekatan Stuctural Equation Modeling untuk analisis faktor yang mempengaruhi produktifitas dari tinjauan keselamatan, kesehatan, dan lingkungan kerja di PT.Barata Indonesia (Persero) Gresik. Pascasarjana Teknik 
Industri-ITS, Kampus ITS Surabaya. Available : $\quad \underline{w w w . i t s . a c . i d / . . . / ~ 2895-~}$ m_sritomo-ie-Makalah\%20.

23. Lienhardt C, et all, 2003. Risk Factors for Tuberculosis Infection in Children in Contact With Infectious Tuberculosis Cases in The Gambia, West Africa. the American Academy of Pediatrics. All rights reserved. Print ISSN: 0031-4005. Online ISSN: 1098-4275. Downloaded from pediatrics. publications.org at Indonesia:AAP Sponsored on September 24, 2011.

24. Hsien-Ho Lin at-all, 2007. Tobacco Smoke, Indoor Air Pollution and Tuberculosis: A Systematic Review and Meta-Analysis. Department of Epidemiology, Harvard School of Public Health, Boston, Massachusetts, United States of America, available from : www.plosmedicine.org

25. Hassmiller KM. 2006. The Association Between Smoking and Tuberculosis. Department of Health Management and Policy. School of Public Health. University of Michigan. 2006 Jan;Vol.48.

26. Davies, P.D.O., 1993, Hubungan antara merokok dengan tuberculin, warta TB, 02/IX:1-7.

27. Aditama, T.Y. 2008. Meyakini bahwa merokok terkait dengan kejadian TB Paru. Available from http://cybermed.cbn.net.id/ cbprtl/ cybermed// detail.aspx? $\mathrm{x}=$ Health+News \&y=cybermed $|0| 0|5| 443.8$

28. Wuaten, G. (2010). Hubungan antara kebiasaan merokok dengan penyakit TB paru. Dipetik juli 23, 2013, dari Http://fkm. unsrat.ac.id/wpcontent/uplads/ 2012/10/ Grace-Wuaten.pdf.

29. Ruhana H, 2008. Hubungan Pola Asuh Anak dengan Status Gizi Balita Umur 24-59 Bulan, Di Wilayah Terkena Tsunami Kabupoten Pidie Propinsi Nangroe Aceh Darussalam. USU Repository. Availabel : repository. usu.ac.id /bitstream/... / 1/09E00172.pd

30. Atmarita dan Tatang, S. 2004. Analisis Situasi Gizi dan Kesehatan Masyarakat dalam Widya Karya Nasional Pangan dan Gizi VIII. Ketahanan Pangan dan Gizi di Era Otonomi Daerah dan Globalisasi, Jakarta, 17-19 Mei 2004
31. Scrimshaw NS, Taylor CD, Gordon JE. Interactions of Nutrition and Infection. Monograph. Geneva. WHO, 1968

32. Harries AD, Thomas J, Chug KS. Malnutrion in Africant patients with pulmonary Tuberculosis. Hum Nutr 1985; 39. P 3613.

33. Harries AD, Nkhoma WA, Thomson PJ, Nyangulu DS, Wirima JJ. Nutritional Status in Malawian patients with pulmonary tuberculosis and respnse to chemoterapy. Eur J Clin Nutr 1988; 42, p 445-50.

34. Onwubalili JK. Malnutrition among tuberculosis patients in Harrow, England. Eur J Clin Nutr 1988; 42, p 363-3

35. Anwar, K. 2008. Analisis Determinan Pengeluaran Rumah Tangga Masyarakat Miskin di Kabupaten Aceh Utara, USU eRepository

36. Mahpudin, 2004. Hubungan faktor lingkungan fisik rumah, sosial ekonomi dan respon biologis terhadap kejadian tuberkulosis paru BTA positif padapenduduk dewasa di Indonesia.

http://lontar.ui.ac.id/opac/themes/ libri2/ detail.jsp?id=107053\&lokasi=lokal

37. Beaglehole, R. Dasar-dasar Epidemiologi. World Health Organization, Geneva. 1993.

38. Mukono. 2000. Prinsip Dasar Kesehatan Lingkungan. Airlangga University Press.Surabaya.

39. Suhardi, Widarsih, D., Nuryadani, dkk. 2006. Hubungan Faktor Risiko Kondisi Rumah Terhadap Kejadian TB Paru Pada Balita Di Wilayah Kota Salatiga Tahun 2006. (On-line) http://www.litbang.depkes.go.id. Diakses 26 mei 2008.

40. Khadijah A, Perwitasari D, 2013. Kondisi Fisik Rumah dan Perilaku dengan Prevalensi TB Paru di Propinsi DKI Jakarta, Banten dan Sulawesi Utara. Media Litbangkes Vol 23 No. 4, Des 2013, 172-181.

41. Firdiana P ; Cahyati WH. 2007. Hubungan antara Luas Ventilasi dan Pencahayaan Rumah dengan Kejadian Tuberculosis Paru Anak di Wilayah Kerja Puskesmas Kedungmundu, Kecamatan Tembalang Semarang Tahun 2007. KEMAS - Volume 3 / No. 2 / Januari - Juni 2008. 
42. Lubis, P. 1989. Perumahan Sehat. Jakarta: Depkes RI.

43. Menteri Kesehatan RI. Keputusan Menteri Kesehatan Republik Indonesia No.829/MenKes/SK/VII/1999 tentang Persyaratan Kesehatan Perumahan.

44. Cozby PC. 2009. Methods in Behavioral Researh Edisi ke 9. Pustaka Pelajar. Jakarta

45. Hastono. 2001. Modul Analisis Data. FKM UI Press, Jakarta.

46. Hasan, I. 2004. Analisis Data. Fakultas Kesehatan Masyarakat UI, Jakarta

47. Gordis L. 2008. Epidemiology. Johns Hopkins Bloomberg School of Public Health Fourth Edition ISBN 978-1-4160-4002-6 Availabel : http://www. Ebook4doctors blocspot.com. Diakses tanggal 20 Maret 2011.

48. Rothman KJ, Greenlan S, Last TL. Modern Epidemiologi third Edition. http://www. Ebook4doctors blocspot.com. Diakses tanggal 20 Maret 2011.

49. Ozcaglar C, at all, 2012. Epidemiological models of Mycobacterium tuberculosis complex infections. Availabel : journal homepage: www.elsevier.com/locate/mbs

50. Departemen Kesehatan RI, 2007. Diagnosa dan Tata Laksanan Tuberkulosis Anak. Kelompok Kerja TB Anak Depkes - IDAI.

51. Azwar, S., 2007. Sikap Manusia, Teori Dan Pengukurannya, Edisi Ke 2, Jakarta: Pustaka Pelajar

52. Machfoedz I, 2007. Teknik Membuat Alat Ukur Penelitian Bidang Kesehatan, Keperawatan, dan Kebidanan Cetakan ketiga. Fitramaya. Yogyakarta.

53. Suhr DD. SEM for Health, Business and Education. http://www2.sas.com/ proceedings/ sugi27/p243-27.pdf. Diakses tanggal 23 Maret 2011

54. Kemenkes RI. 2010. Laporan Nasional Riset Kesehatan Dasar (Riskesdas) Tahun 2010. http://www.litbang.depkes.go.id. Diakses tanggal 8 Juni 2011.

55. Dinas Kesehatan Propinsi Jawa Tengah 2007a . Pertemuan Sosialisasi Survei Tuberkulin. Semarang.
56. CDC. Guidelines for preventing the transmission of Mycobacterium tuberculosis in healthcare settings, 2005. MMWR 2005; 54 (No. RR-17). $\quad$ www.cdc.gov/mmwr/ preview/mmwrhtml/rr5417a1.htm?s_cid=rr 5417a1_e

57. Ozcaglar C, at all, 2012. Epidemiological models of Mycobacterium tuberculosis complex infections. Availabel : journal homepage: www.elsevier.com/locate/mbs

58. CDC. Transmission and Pathogenesis of Tuberculosis, 2005. Centers for Disease Control and Prevention National Center for HIV/AIDS, Viral Hepatitis, STD, and TB Prevention Division of Tuberculosis Elimination Atlanta, Georgia 2008 www.cdc.gov/tb

59. World Health Organization. 2003. International Travel And Health. WHO, Geneva. (Online).http://www.who.int/ gpt/publication/index.htm. Diakses tanggal 7Maret 2010.

60. Badan Litbangkes Depkes RI, 2007, Riset Kesehatan Dasar 2007, Jakarta

61. Khadijah A, Perwitasari D, 2013. Kondisi Fisik Rumah dan Perilaku dengan Prevalensi TB Paru di Propinsi DKI Jakarta, Banten dan Sulawesi Utara. Media Litbangkes Vol 23 No. 4, Des 2013, 172-181.

62. Abraham Maslow, 2009. Teori Hirarki Motivasi, http:// rajapresentasi.com/ 2009/03/teorihirarki-motivasi-dari-abraham-maslow/ (diakses15 April 2014).

63. Dudeng, D., Naning R. dan Pramono D. 2006. Faktor-Faktor yang Berhubungan dengan Kejadian Tuberkulosis pada Anak. Berita Kedokteran Masyarakat Vol. 22 No. 2.

64. Handayani, 2002. Respon Imunitas Seluler pada Infeksi Tuberkulosis Paru, Pusat Penelitian Pemberantasan Penyakit, Badan Penelitian dan Pengembangan Kesehatan Departemen Kesehatan RI, Jakarta. Availabel : http. www.kalbe.co.id/cdk

65. Eley BS and Beatty DV,2009. The basic immunology of tuberculosis, Saunders Elsevier

66. Sudiana, 2011. Konsep Dasar Imunologi. Staf Pengajar : Fakultas Kedokteran Universitas Airlangga Program 
Pascasarjana Universitas Airlangga

Availabel From

http://www.ners.unair.ac.id/materikuliah/D

ASAR\%2 0I MUNOLOGI. pdf

67. In KS, 2006. Tuberculosis Pada Anak. Fak. Kedokteran Univ. Wijaya Kusuma Surabaya. Availabel : http://last3arthtree.files. wordpress.com/ 2009/02/tb-pada-anak.pdf

68. Wahyunu, 2008. Determinan Perilaku Masyarakat dalam Pencegahan, Penularan Penyakit TBC di Wilayah Kerja Puskesmas Bendosari. GASTER, Vol. 4, No. 1 Februari 2008 (178 - 183). Diakses 14 April 2014.

69. Sukana B, Aspek Pengetahuan, Sikap dan Perilaku Masyarakat kaitannya dengan Penyakit TB Paru. Media Litbang Kesehatan Volume 21 Nomor 1 Tahun 2011

70. Hermawan Y. 2005. Hubungan antara Tingkat Pendidikan dan Persepsi dengan Perilaku Ibu Rumah Tangga dalam Pemeliharaan Kebersihan Lingkungan. Akses online http://ejournal.unud.ac.id diakses pada tanggal 6 Juni 2011

71. Crofton, J., Horne, N., Miller, F., 2002. (Alih Bahasa Prof. Dr. Muljono dkk) : Tuberkulosis Klinik.Widiya Medika, Jakarta

72. Farida JR, 2005. Studi Perbandingan Aktivitas Fagositosis Makrofag terhadap Mycobacterium TuberculosisSensitif dan Resisten Isoniazid. LOGIKA, Vol. 2, No. 2, Juli 2005 